University of Warwick institutional repository: http://go.warwick.ac.uk/wrap

This paper is made available online in accordance with publisher policies. Please scroll down to view the document itself. Please refer to the repository record for this item and our policy information available from the repository home page for further information.

To see the final version of this paper please visit the publisher's website. Access to the published version may require a subscription.

Author(s): Wiji Arulampalam with Alison L. Booth \& Mark L. Bryan Article Title: Is There a Glass Ceiling over Europe? Exploring the Gender Pay Gap across the Wage Distribution

Year of publication: 2007

Link to published version: http://www.ilr.cornell.edu/ilrreview/articles.html 
IZA DP No. 1373

\section{Is There a Glass Ceiling over Europe?}

Exploring the Gender Pay Gap across the Wages Distribution

Wiji Arulampalam

Alison L. Booth

Mark L. Bryan

October 2004 


\title{
Is There a Glass Ceiling over Europe? Exploring the Gender Pay Gap across the Wages Distribution
}

\author{
Wiji Arulampalam \\ University of Warwick \\ and IZA Bonn \\ Alison L. Booth \\ Australian National University, University of Essex, \\ CEPR and IZA Bonn \\ Mark L. Bryan \\ University of Essex
}

Discussion Paper No. 1373

October 2004

\author{
IZA \\ P.O. Box 7240 \\ 53072 Bonn \\ Germany \\ Phone: +49-228-3894-0 \\ Fax: +49-228-3894-180 \\ Email: iza@iza.org
}

Any opinions expressed here are those of the author(s) and not those of the institute. Research disseminated by IZA may include views on policy, but the institute itself takes no institutional policy positions.

The Institute for the Study of Labor (IZA) in Bonn is a local and virtual international research center and a place of communication between science, politics and business. IZA is an independent nonprofit company supported by Deutsche Post World Net. The center is associated with the University of Bonn and offers a stimulating research environment through its research networks, research support, and visitors and doctoral programs. IZA engages in (i) original and internationally competitive research in all fields of labor economics, (ii) development of policy concepts, and (iii) dissemination of research results and concepts to the interested public.

IZA Discussion Papers often represent preliminary work and are circulated to encourage discussion. Citation of such a paper should account for its provisional character. A revised version may be available directly from the author. 


\section{ABSTRACT \\ Is There a Glass Ceiling over Europe? Exploring the Gender Pay Gap across the Wages Distribution*}

Using harmonised data from the European Union Household Panel, we analyse gender pay gaps by sector across the wages distribution for ten countries. We find that the mean gender pay gap in the raw data typically hides large variations in the gap across the wages distribution. We use quantile regression (QR) techniques to control for the effects of individual and job characteristics at different points of the distribution, and calculate the part of the gap attributable to differing returns between men and women. We find that, first, gender pay gaps are typically bigger at the top of the wage distribution, a finding that is consistent with the existence of glass ceilings. For some countries gender pay gaps are also bigger at the bottom of the wage distribution, a finding that is consistent with sticky floors. Third, the gender pay gap is typically higher at the top than the bottom end of the wage distribution, suggesting that glass ceilings are more prevalent than sticky floors and that these prevail in the majority of our countries. Fourth, the gender pay gap differs significantly across the public and the private sector wages distribution for each of our EU countries.

JEL Classification: J16, J31, J7

Keywords: $\quad$ glass ceilings, sticky floors, quantile regression, public sector, gender pay gaps

Corresponding author:

Wiji Arulampalam

Department of Economics

University of Warwick

Coventry, CV4 7AL

United Kingdom

Email:wiji.arulampalam@warwick.ac.uk

\footnotetext{
${ }^{*}$ The support of the Leverhulme Trust is gratefully acknowledged. Thanks also to participants of the $7^{\text {th }}$ Labour Econometrics Conference, Auckland, 13-14 August 2004 for helpful comments.
} 


\section{INTRODUCTION}

While the mean gender wage gap has been extensively investigated in the labour economics literature, only relatively recently has attention shifted to investigating the degree to which the gender gap might vary across the wages distribution and why. Albrecht, Bjorklund and Vroman (2003) use 1998 data for Sweden and show that the gender wage gap is increasing throughout the conditional wage distribution and accelerating at the top, and they interpret this as evidence of a glass ceiling in Sweden. Dolado and Llorens, (2004) undertake a similar analysis using 1998 data for Spain. They stratify their sample by education group and find that the gender wage gap is expanding over the wage distribution only for the group with tertiary education. For less educated groups, the gender wage gap is wider at the bottom than the top. Thus in Spain for the more educated there is a glass ceiling while for the less educated there is not.

The purpose of our paper is to investigate these issues further in order to see if the glass ceiling phenomenon is prevalent across pre-enlargement Europe. Using harmonised data from the European Union Household Panel, we analyse gender pay gaps by sector (private or public) across the wages distribution for eleven countries utilizing the quantile regression $(\mathrm{QR})$ framework. We investigate the extent to which gender affects the location, scale and shape of the conditional wage distribution, and whether or not these patterns differ across the public and private sectors.

We first chart the gender pay gap using raw data and then compare the raw gender gaps with estimates which control for men's and women's attributes using QR. This enables us to answer the question of how much of the observed gender pay gaps remain after controlling for differences in characteristics across men and women. Unlike ordinary least squares (OLS), QR methods allow for the possibility that characteristics may have 
different returns at different points of the distribution. We find that, for most of our countries in both the public and private sectors, the average gender wage gap can be broken up into a gap that is typically wider at the top and occasionally also wider at the bottom of the conditional wage distribution. We interpret the gender wage gap at the top of the wage distribution as a glass ceiling, whereby women otherwise identical to men can only advance so far up the pay ladder. At the bottom of the wage distribution, in some of our EU countries, we also find that the gender pay gap widens significantly. We define this phenomenon as a sticky floor. ${ }^{1}$ We find that differences in returns account for a large part of the variation in the gender pay gap across the conditional wages distribution. In the conclusion of the paper we discuss the various additional hypotheses that could explain the empirical findings.

\section{THE DATA, VARIABLES AND RAW GENDER WAGE GAP}

Our data are from the European Community Household Panel (ECHP), a large-scale survey collected annually since 1994 in a standardised format that facilitates cross-country comparisons. We include in our analysis the eleven European countries listed in Table $1 .^{2}$ We initially estimated the gender pay gap separately for waves 2 and 8 , in order to chart any changes that might have occurred between 1995 and 2001. Since there was little difference between the two sets of estimates, in our main model we estimate the gender gap over the entire sample of waves 2 to 8 inclusive, ${ }^{3}$ pooling all the waves and also

\footnotetext{
${ }^{1}$ Booth, Francesconi and Frank (2003) defined a sticky floor as the situation arising where otherwise identical men and women might be appointed to the same pay scale or rank, but the women are appointed at the bottom and men further up the scale. Such a strategy can evade some discrimination laws, since the appointment rank is the same.

2 We omit Greece and Portugal from our estimation owing to apparent gaps in the training data and because of the smaller estimating sub-samples with usable information.

${ }^{3}$ We omitted wave 1 because first, it does not contain information about whether or not the respondent's employment contract was fixed term / casual. If temporary contract coverage varies between men and women, temporary contracts could be an important determinant of the gender wage gap. Second, the deflator used (the EU harmonised index of consumer prices, from Eurostat) is only available from wave 2. Also note that Austria did not join the ECHP until wave 2 and that Finland did not join until wave 3
} 
including wave dummies as explanatory variables in addition to the usual set of exogenous variables. For the pooled sample we do not require individuals to be present in all waves or in consecutive waves, and we thus have new entrants across waves. In addition we lose some individuals through attrition. Thus we have a changing composition of individuals. This can be in our favour: in the absence of panel techniques (unavailable with current QR technology) we do not need to sample the same individuals in several waves, and a changing composition can introduce more variation into the sample. For all countries we estimate two specifications: first, excluding industry and occupation, and second, including these variables. We estimate each specification separately by country and gender.

Because we wish to avoid conflating issues to do with gender and early educational enrolments, we exclude from our analysis individuals under the age of 22 years, and paid apprentices and those on special employment-related training schemes (who account for less than $1 \%$ of the sampled age group). Amongst older workers there may also be differential withdrawal from the labour force, depending, for example, on how early retirement schemes operate. We therefore exclude workers of 55 years and over. For each country, our estimating sub-samples - stratified by gender - comprise fulltime and part-time public and private sector employees who are: (i) between the ages of 22-54 years inclusive; (ii) working at least 15 hours per week; (iii) not employed in agriculture; and (iv) with valid observations on all the variables used in the wage equations. The restriction of working at least 15 hours per week was necessary because of the nature of the ECHP data, where - in the first two waves - we were unable to distinguish individuals regularly working fewer than 15 hours from those out-of-the labour force. In addition, for those working fewer than 15 hours, the ECHP across all waves 
provides no information on firm size, public/private sector or tenure. Thus our estimating sub-samples will under-represent low-hours part-timers. ${ }^{4}$

The last column of Table 1 gives the number of pooled observations for each country and sector used in the estimations. Thus, for example, the first row of the Table shows that Austrian public sector sub-sample comprises 2389 male and 2214 female person-year observations, while in the private sector there are 6469 male and 4205 female person-year observations. For Britain, the public sector is proportionately smaller, with 2099 male and 3918 female pooled observation compared to 8980 male and 6934 female observations in the private sector.

The dependent variable is the log of the average hourly wage, including overtime payments, in the respondent's main job, deflated to 2001 prices. ${ }^{5}$ The deflators are the European Union's harmonised indices of consumer prices (HICP; see Eurostat Yearbook 2003).

We stratify by sector because institutions in the public and private sector are typically very different. In the public sector, organisations are largely non-profit and thus isolated from the rigours of the market economy. Thus, in principle they could more easily follow "tastes for discrimination" in their wage-setting behaviour. However, they are also subject to government objectives and policies. The European Union countries have adopted strong positions in favour of equal opportunities and it is likely that these might be more enforced in the public sector. We tested to see if this is a valid separation by utilizing simple OLS pooling tests, which in every country rejected joint equality of the public-private sector coefficients.

\footnotetext{
4 Although for most countries, they represent only a tiny fraction of workers. Exceptions are Britain $(6.4 \%$ of the sub-sample), Denmark (3.2\%), the Netherlands (9.8\%) and Ireland (4.0\%). In all other countries the proportion of low-hours part-timers is under $3 \%$.

5 The log wage was calculated from the ECHP variables as log (wage) $=\log (\mathrm{PI} 211 \mathrm{MG} *(12 / 52) /$ $\mathrm{PE005A})=\log ($ normal gross monthly earnings from main job including overtime $*(12 / 52) /$ hours in main job including overtime). No specific information is provided on overtime hours and premia.
} 
Column [1] of Table 1 indicates the male percentage of the combined male and female samples for the public and the private sectors separately by country. The public sector has a majority female workforce in seven of our eleven countries. Only in Austria, Ireland, Italy and Spain are men in the majority in the public sector, and even in these countries, the majority is slim (the highest proportion of men is $52.7 \%$ in Spain). In the private sector, on the other hand, men predominate across all countries, and in six countries they account for over $60 \%$ of the private sector workforce.

In Figure 1, we plot the raw hourly wage distributions for men and women in each country. In general, the distribution of men's wages is shifted to the right compared to that of women's wages. This location shift is reflected in positive mean (and median) gender pay gaps in each country, which we discuss below. The two distributions are perhaps most similar in the Italian public sector, where they nearly coincide, and indeed here we find that the mean and median raw wage gaps are positive but not statistically significant. In the other countries and sectors, it is evident that not only the location, but also the scale and shape of the distributions differ between men and women. See, for example, the graphs for the Finnish public sector. These differences of scale and shape imply that the gender pay gap is not constant over the wage distribution. Therefore, measuring the gender pay gap at the mean of each distribution, i.e. comparing an 'average' woman with an 'average' man, can produce a misleadingly simple picture of how men's and women's wages differ. This mean gap can hide larger or smaller gaps between high-paid men and women, or between low-paid men and women. ${ }^{6}$ To quantify this variation, columns [2] to

\footnotetext{
${ }^{6}$ Although it is not obvious from Figure 1, where the country graphs are scaled individually, overall wage inequality differs substantially across countries. In our data, the countries with the most compressed raw log hourly wage distributions (public and private sectors combined) are Denmark followed by Italy, the Netherlands, Finland and Belgium, and then Austria. The country with the most unequal wages distribution is Ireland, followed by Spain, Britain and France and Germany. The $90^{\text {th }}-10^{\text {th }}$ percentile differentials of the raw $\log$ wage distributions are: Austria $0.94 \log$ points; Belgium $0.90 \log$ points; Britain 1.20 log points; Denmark $0.72 \log$ points; Finland $0.90 \mathrm{log}$ points; France $1.13 \log$ points; Germany $1.01 \log$ points; Ireland $1.32 \log$ points; Italy $0.88 \log$ points; Netherlands $0.89 \log$ points; and Spain $1.30 \log$ points.
} 
[7] of Table 1 report the raw wage gap measured at various points of the unconditional wage distribution.

As already noted, the raw wage gap measured at the mean is generally higher in the private sector than in the public sector. The raw average gender wage gap in the public sector is in excess of $20 \%$ in Britain, Finland and the Netherlands, while in Belgium, Italy and Spain it is under $10 \%$, and indeed in Italy it was found to be insignificantly different from zero. In contrast, in the private sector, the raw average gender gap exceeds $13 \%$ in all countries and in Britain and Austria, it is found to be close to $30 \%$. In France, Germany, Ireland, the Netherlands and Spain the gap is around or over $20 \%$.

How does the raw gender wage gap vary across the unconditional distribution? In the public sector, as suggested by the raw distributions, Italy is the only country where the raw gender gap is found to be insignificant in all parts of the distribution except at the top (see Column [7]), where it is still very much smaller (at about 5\%) than other countries. In Finland and the Netherlands, the raw gap increases monotonically as we move up the unconditional wage distributions, and in Belgium, Denmark and Germany, the gap is also higher toward the top of the distribution. In Ireland and Spain, the gap moves in the opposite direction. In Britain, the raw gap is remarkably similar at about $20 \%$ across different parts of the distribution. These raw gaps are also illustrated in Figure 2.

We find similar patterns in the private sector too. Britain exhibits a similar wage gap along the distribution. The gender gap increases up the wage distribution in Finland and Netherlands, and is also higher toward the top in Belgium, Denmark, France and Ireland. In contrast to what is found in the public sector in Italy, the wage gap is now significantly different from zero and is U-shaped. We find a similar pattern in Germany. 
In summary, we find that in both the public and the private sectors there is a tendency for the gender wage gap to be higher at the top of the unconditional wage distribution relative to the middle parts of the distribution, hinting at a possible 'glassceiling' effect. However, the gender wage gap is also wider at the bottom end too for public sector workers in six countries (Austria, Belgium, Britain, Denmark, France and Spain), and for private sector workers in four countries (France, Germany, Italy and Spain). This hints at a sticky floors effect for some countries. But these are only raw gender gaps. In order to find out how much of the observed raw wage gap can be explained by the differences in the returns to various characteristics, we next turn to the quantile regression results.

\section{WAGE GAP ESTIMATES FROM QUANTILE REGRESSIONS}

\section{(a) The Econometric Model}

There is now an extensive literature that estimates gender pay gaps using a decomposition of the linear regression framework first introduced by Blinder (1973) and Oaxaca (1973). In this framework, log-linear wage regressions are estimated using the male and female sub-samples and then the differences in the coefficient estimates, multiplied by a set of characteristics, is attributed to the wage differential for an individual with that particular characteristic. Here, we deviate from this common practice by looking at the effects of gender and other covariates on different quantiles of the log wage distribution. ${ }^{7}$ The effects of covariates on the location, scale and shape of the conditional wage distribution can be easily estimated using a quantile regression $(\mathrm{QR})$ framework. This is a major advantage compared to the linear or least squares regression model, which yields only the effects on the location - the conditional mean of the distribution. Since the QR framework

\footnotetext{
7 The linear conditional quantile regression model was first introduced by Koenker and Bassett (1978). For a recent survey of these models, see Buchinsky (1998).
} 
allows the characteristics to have different returns at different quantiles, at each point of the distribution it can control more fully for differences between men and women's wages that are attributable to their characteristics.

Following Buchinsky (1998), we specify the $\theta$ th $(0<\theta<1)^{8}$ conditional quantile of the log wage $(w)$ distribution for the $i$-th individual $(i=1, \ldots, n)$ in wave $\mathrm{t}\left(t=1, \ldots, T_{i}\right)$ as

$$
\operatorname{Quant}_{\theta}\left(w_{i t} \mid \mathbf{x}_{i t}\right)=\alpha(\theta)+\mathbf{x}_{i t}{ }^{\prime} \boldsymbol{\beta}(\theta)
$$

implying

$$
w_{i t}=\alpha(\theta)+\mathbf{x}_{i t}{ }^{\prime} \beta(\theta)+u_{\theta i t}
$$

with $\operatorname{Quant}_{\theta}\left(u_{\theta i t} \mid \mathbf{x}_{i t}\right)=0$.

For each sector, we estimate this model for men and women separately. Note that, if the underlying model were truly a location model - in the sense that the changes in explanatory variables caused only a change in the location of the distribution of $w$ and not in the shape of the distribution - then all the slope coefficients would be the same for all $\theta .{ }^{9}$ We use Stata 8 to estimate the coefficients of our QR model.

The gender gap at the $\theta$ th quantile due to differing returns (that is adjusted for characteristics) is given by

$$
\operatorname{Gap}(\theta)=\mathbf{x}_{m}(\theta)^{\prime}\left[\boldsymbol{\beta}_{m}(\theta)-\boldsymbol{\beta}_{f}(\theta)\right]
$$

where $\mathbf{x}_{m}(\theta)$ are the mean characteristics of men at the $\theta$ th quantile, $\boldsymbol{\beta}_{m}(\theta)$ are the returns for men at the $\theta$ th quantile, and $\beta_{f}(\theta)$ are the returns for women at the $\theta$ th quantile. The gap is the difference in pay which women would face at the $\theta$ th quantile if they had the typical characteristics of men at that quantile. ${ }^{10}$ We describe in more detail below how we derive the appropriate vector of characteristics at each quantile.

\footnotetext{
${ }^{8} \theta=0.5$ refers to the Median.

9 Quantile regression models are more general than simple linear regression model allowing for heteroskedastic errors, since the QR model allows for more general dependence of the distribution of $w$ (the dependent variable) on the $\mathbf{x s}$ instead of just the mean and the variance alone.

${ }^{10}$ We also calculated the gap using women's characteristics as the reference. The results were very similar.
} 


\section{(b) The Estimates}

As noted above, we estimate the models separately by gender, sector and country, and thus have 44 sets of estimations for each specification. In the interests of space, and given the focus of our paper, we do not provide the complete set of estimates for each country. Instead we move straight to the calculations of the gender wage gap obtained from the QR model. Full details of all estimated effects for each country can be obtained from the authors on request. The calculations enable us to see whether or not there is a glass-ceiling effect over Europe and to determine if there is also a sticky floor.

For each country, we estimate the quantile regressions for each gender by sector. We estimated all models with and without controls for occupation and industry, but with each variant including the full set of other controls given at the bottom of Table 2 (including wave dummies). In Table 2 and Figure 2, we report the results from the wage gap calculations obtained from the model including controls for occupation and industry. Figure 3 illustrates the results where occupation and industry are excluded.

We now provide more details of our calculations. First, we estimated the quantile regressions for each gender by sector. Then we calculated the predicted wage at different parts of the wages distributions by gender and sector. The wage gap in which we are interested measures the difference in the returns to men and women when men's characteristics are used in the counterfactual calculations. A positive wage gap implies that the returns to men's characteristics are higher than those of women, and a negative gap implies the reverse. Instead of using average characteristics of the male sample to calculate the counterfactuals, we follow the procedure suggested by Machado and Mata (2000) and use the characteristics of males who are in that particular quantile of interest. ${ }^{11}$ In practical terms, this involves first drawing a sample of 101 individuals randomly (with

\footnotetext{
${ }^{11}$ This is similar to the procedure that has been used by Albrecht et. al (2003) and Dolado and Llorens (2004).
} 
replacement) from the male database and then sorting the observations by wage in order to get an observation for each percentile. The procedure is then repeated 500 times and we then calculate the average wage and the characteristics for each quantile of interest.

The wage gap estimates obtained in this fashion are reported in Table 2, together with the percentage of raw gap that is explained by the conditional model. ${ }^{12}$ To facilitate comparison with the usual procedure, we report - in the first column of Table 2 - the gender wage gap estimated from ordinary least squares (OLS) using average male characteristics. To conserve space, we do not report standard errors. However, in Figure 2, we present the estimated gender wage gap for each quantile of the log wage distribution along with the $95 \%$ confidence band around these estimates. Superimposed on the plots is a dotted horizontal line representing the wage gaps estimated from the mean regressions.

The first interesting point to note from this table - and from Figure $2-$ is that all the estimated gender wage gaps from the conditional model are positive, both in the public and the private sector. In other words, across the conditional wages distributions in all countries, otherwise identical men and women receive different returns to their identical characteristics. Notice also that these estimates are all significantly different from zero at $1 \%$ or less significance level.

First, consider the public sector estimates, shown in the top panel of Table 2. Except for Austria, Germany and Ireland, the gender wage gap is highest at the $90^{\text {th }}$ percentile of the conditional wage distribution in the public sector compared to other parts of the distribution, pointing to a glass ceiling effect. The highest wage gap, of $31 \%$, is found at the $90^{\text {th }}$ percentile in Finland. There is also some evidence of sticky floors, but in only four countries - Austria, Belgium, Germany and Ireland - where women at the

\footnotetext{
${ }^{12}$ The controls included in the equations are listed under Table 2. As well as human capital variables and job characteristics, they include year dummies to allow for cyclical effects on the gender wage gap at each quantile. Unfortunately, the ECHP contains no information about individual union membership or coverage by collective bargaining.
} 
bottom $\left(10^{\text {th }}\right.$ percentile $)$ are found to be highly disadvantaged relative to those at the $25^{\text {th }}$ percentile. In Ireland, the estimated wage gap across the wages distribution varies from a figure of about $15 \%$ (at the $75^{\text {th }}$ percentile) to about $40 \%$ (at the $25^{\text {th }}$ percentile), while the mean gap from the OLS regression is $20 \%$. In common with the other countries therefore, the wage gap at the mean provides a very incomplete picture of the differing returns faced by women and men at various points of the wages distribution.

Second, consider the private sector estimates, shown in the bottom panel of Table 2. With the exception of Belgium, Britain and Germany, the private sector exhibits a similar pattern to that of the public sector. Again, Finland has the highest gender wage gap (30\%) at the top of the distribution. Only in Austria, Belgium, Britain and Germany does the gender wage gap not increase as we move up the conditional wages distribution. There is some evidence of sticky floors, but only in Austria and France, where the gap at the $10^{\text {th }}$ percentile is about 4 percentage points higher than at the $25^{\text {th }}$ percentile.

We next turn to the proportion of the observed raw wage gap that is explained by the differences in returns to characteristics, shown in the second row for each country in Table 2. A negative value implies that women have characteristics that compensate them for any "discrimination" - defined here as different returns to the same characteristics that they face in the labour market. For example, in the public sector in six countries Austria, Belgium, France, Ireland, Italy and Spain - women typically have better characteristics than men. The same is also true for British and French women earning in the top parts of the distribution, and for German women in the bottom parts of the distribution. ${ }^{13}$ Women working in the private sector in Austria, Belgium, Finland, Italy and Spain, and in the top part of the distribution, also seem to have better characteristics than men. In the private sector, Finland and Italy are the only two countries where women

\footnotetext{
${ }^{13}$ The very negative values of public sector Italy and Ireland merit some comment. Taking the Italian case, it arises because there is basically no gap in the raw data, but a large one when characteristics are controlled for. So the "discrimination effect" is a big percentage of the raw gap.
} 
have better characteristics than men in all parts of the distribution to compensate for the different returns that they would face in the labour market for the same characteristics as men.

The estimates just discussed include controls for occupation and industry. Because these variables may be endogenous if individuals choose occupation and industry based on earnings prospects, we also estimated models without occupation and industry controls. The results are summarised in Figure 3, and are remarkably similar to the previous estimates. They suggest that our conclusions are robust to the possible endogeneity of occupation and industry, but also that segregation of women into certain occupations and industries is not a major driver of the gender pay gap.

\section{DISCUSSION AND CONCLUSIONS}

In the preceding discussion we interpreted the gender pay gap as due to discrimination, since otherwise identical men and women received different returns to the same observed characteristics. We now consider why the observed gender pay gaps in Europe are: (i) in most countries, larger at the top of the wages distribution (glass ceilings); and (ii) in some countries also larger at the bottom of the wages distribution (sticky floors). Of necessity our discussion is speculative. We hope that future work - with richer data containing linked employer-employee information - might be able to investigate some of these hypotheses more fully. ]

In the private sector, only Germany and Ireland do not exhibit a glass ceiling at the top of wages distribution. And the only countries in which a public sector glass ceiling is not observed are Austria and Germany. Thus it is fair to respond, in answer to the question posed in our paper's title, that there is a glass ceiling over Europe. But what might cause this? Albrecht et al (2003: 172), charting the extent of the Swedish glass ceiling and speculating as to its causes, also note that gender differences in returns are the primary 
factor. They reject the notion of a 'taste-based explanation ...[whereby] Swedish women prefer to work in family-friendly but low-wage jobs', on the grounds that gender differences arise from differences in rewards even after controlling for occupation. Instead they hypothesise that a more likely candidate explanation is the 'work environment faced by Swedish women' especially 'the Swedish parental leave policy and the daycare system', which provide strong incentives to participate but not to commit strongly to a career.

This is an interesting conjecture and one that is supported by our results for Denmark. Denmark is a very similar country to Sweden with regard to both female participation and the OECD (2001) index of 'work-family reconciliation policies' and it too has a glass ceiling. Nonetheless, the fact that we find the same glass ceiling effect across most of our EU countries, with their very different parental leave policies and daycare systems, leads us to speculate that this cannot be the primary explanation. For example, Spain, Italy and Ireland have low levels of female participation and low levels of 'work-family reconciliation policies' yet - with the exception of the private sector in Ireland - they too exhibit a glass ceiling. ${ }^{14}$

A second reason put forward by Albrecht et al (2003) for the glass ceiling phenomenon is the relatively high wages at the bottom of the wage distribution making it 'very difficult for career-oriented women to hire household help or help with child care', especially for the very young children under 12 months who cannot be admitted into daycare. For this reason, women might be found in less-demanding jobs and thus fall substantially behind men towards the top of the distribution. Thus cross-country evidence should show a negative correlation between the magnitude of the glass ceiling and the dispersion of the wages distribution. We estimated this relationship for our sample of

\footnotetext{
${ }^{14}$ We also estimated the impact of the OECD index of work-family reconciliation policies on the glass ceiling (measured as the difference between the $90^{\text {th }}$ and the $50^{\text {th }}$ percentile from Table 2) and found no correlation.
} 
eleven countries. While indeed finding a negative correlation, the relationship is statistically insignificant. ${ }^{15}$

Of course other factors are also likely to be at work. Many labour markets are hierarchical, and promotions and appointments procedures can exacerbate gender pay gaps. While promotions are typically subject to well-defined procedures, especially in larger organisations, exactly where in the rank-specific salary scale a successful candidate is appointed can depend on discrimination and individual negotiation in addition to experience. Booth, Francesconi and Frank (2003), using data on promotions from the British Household Panel Survey, show how women do not do as well financially out of promotions as do men, ceteris paribus. ${ }^{16}$ If promotions procedures favour men rather than women towards the top of the wages distribution, then the gender pay gap might be bigger towards the top. Landers, Rebitzer and Taylor (1996) show, in their study of US law firms, how criteria for promotion like excessively long hours of work can exacerbate gender pay gaps towards the top of the lawyers' wage distribution.

Individuals are frequently appointed at a particular level of the rank of the relevant scale for their occupation or industry and then aim to work their way up the hierarchy. While both promotions and pay are covered by anti-discrimination legislation and equal opportunities policies, there is scope for discretion - or discrimination - about the particular level within a rank to which an individual is appointed. ${ }^{17}$ Thus if men are initially appointed at a higher starting salary (a higher rung) within a particular scale, then

\footnotetext{
${ }^{15}$ The dependent variable in the cross-country equation was the glass ceiling (measured as the difference between the $90^{\text {th }}$ and the $50^{\text {th }}$ percentile from Table 2). The explanatory variable was wages dispersion. For the public sector the coefficient was $-0.009(0.11)$ and for the private sector $-0.271(0.85)$ where t-statistics are in parentheses.

${ }^{16}$ Blackaby, Booth and Frank (2002), using data on the UK academic economists' labour market, produce further evidence that promotions might exacerbate gender pay inequality.

${ }^{17}$ Discrimination in the EU is prohibited on grounds of gender, race (including nationality and citizenship) and (in Northern Ireland only) religion. In light of the European Framework Directive, categories covered by anti-discrimination legislation was extended in 2003 to include religion and sexual orientation, and will be extended in 2006 to include the additional categories of age and disability.
} 
the gender pay gap might be bigger towards the bottom of the wage distribution - the sticky floor.

In our ECHP data, the sticky floors phenomenon is observed in private sector France and Italy, and in the public sector in Austria, Belgium, Denmark, France, Germany and Ireland. In these countries women with characteristics identical to men are paid significantly less at the bottom of the wage distribution. This could be due to a variety of reasons, one of which we sketched out above. Another hypothesis is that women towards the bottom might have less bargaining power or be more likely to be subject to firms' market power than comparable men, due perhaps to unobservable family commitments or social custom whereby the man's career takes precedence. Alternatively minimum wage compliance at the bottom may be unequal across gender, or trade unions might differentially represent the interests of their female electorate at the bottom. 


\section{References}

Albrecht, J., Bjorklund, A., and Vroman, S. (2003). Is there a glass ceiling in Sweden? Journal of Labor Economics, vol. 21, no. 1, 145-177.

Blinder, A. (1973). 'Wage discrimination: reduced form and structural estimates', Journal of Human Resources, 8, 436-55.

Booth, A. L, Francesconi, M., and Frank, J. (2003). 'A sticky floors model of promotion, pay and gender', European Economic Review 47(2), 295-322.

Booth, A. L, Frank, J., and Blackaby, D. (2002). 'Outside offers and the gender pay gap', CEPR London Discussion Paper No.

Buchinsky, M. (1998) 'Recent advances in quantile regression models', Journal of Human Resources, 33, 88-126.

Buchinsky, M (2001). 'Quantile regression with sample selection: estimating women's return to education in the U.S.', in Fitzenberger, B., Koenker, R., and Machado, J.A.F. (Eds.) (2001) Economic Applications of Quantile Regression, Physica-Verlag.

Dolado, J. J. and Llorens, V. (2004). 'Gender wage gaps by education in Spain: glass floors vs. glass ceilings', CEPR Discussion Paper No. 4203, London.

Eurostat Yearbook 2003: the statistical guide to Europe: data 1991-2001, Luxembourg: Office for Official Publications of the European Communities.

Koenker, R. and Bassett, G. (1978). 'Regression quantiles', Econometrica, 46, 33-50.

Landers, RM, JB Rebitzer and LJ Taylor (1996) 'Rat Race Redux: Adverse Selection in the Determination of Work Hours in Law Firms. American Economic Review 86(3), 329-348. 
Lucifora, C. and Meurs, D. (2004). 'The public sector pay gap in France, Great Britain and Italy', IZA Discussion Paper 1041, Bonn, Germany.

Machado, J. and Mata, J. (2000). 'Counterfactual decomposition of changes in wage distributions using quantile regression', forthcoming Journal of Applied Econometrics.

Oaxaca, R.L. (1973). 'Male female wage differentials in urban labor markets', International Economic Review, 14(3), 693-709.

OECD (2001) Employment Outlook. June 2001. Chapter 4: "Balancing Work and Family Life: Helping Parents into Paid Employment." Paris: OECD. 
Table 1 - Raw Gender Wage Gap (Standard Error)

\begin{tabular}{|c|c|c|c|c|c|c|c|c|}
\hline & $\begin{array}{c}\text { Males (\%) } \\
\text { [1] }\end{array}$ & $\begin{array}{c}\text { Mean } \\
{[2]} \\
\end{array}$ & $\begin{array}{c}\text { 10 }^{\text {th }} \text { Percentile } \\
{[3]} \\
\end{array}$ & $\begin{array}{c}25^{\text {th }} \text { Percentile } \\
{[4]}\end{array}$ & $\begin{array}{c}\text { Median } \\
\text { [5] }\end{array}$ & $\begin{array}{c}75^{\text {th }} \text { Percentile } \\
{[6]} \\
\end{array}$ & $\begin{array}{c}\mathbf{9 0}^{\text {th }} \text { Percentile } \\
{[7]} \\
\end{array}$ & $\begin{array}{c}\text { No. of Observation } \\
\text { Males, females } \\
{[8]}\end{array}$ \\
\hline \multicolumn{9}{|c|}{ PUBLIC SECTOR } \\
\hline Austria & 51.90 & $0.135(0.012)$ & $0.153(0.011)$ & $0.122(0.011)$ & $0.087(0.011)$ & $0.093(0.017)$ & $0.115(0.018)$ & 2389,2214 \\
\hline Belgium & 47.79 & $0.073(0.011)$ & $0.061(0.016)$ & $0.058(0.013)$ & $0.033(0.013)$ & $0.065(0.014)$ & $0.136(0.019)$ & 2257,2466 \\
\hline Britain & 34.88 & $0.212(0.011)$ & $0.213(0.017)$ & $0.185(0.014)$ & $0.216(0.014)$ & $0.197(0.016)$ & $0.217(0.017)$ & 2099,3918 \\
\hline Denmark & 33.59 & $0.114(0.008)$ & $0.128(0.018)$ & $0.085(0.010)$ & $0.105(0.005)$ & $0.119(0.007)$ & $0.175(0.013)$ & 1984,3922 \\
\hline Finland & 35.04 & $0.259(0.009)$ & $0.164(0.016)$ & $0.196(0.011)$ & $0.260(0.009)$ & $0.316(0.014)$ & $0.307(0.022)$ & 2240,4153 \\
\hline France & 45.06 & $0.116(0.010)$ & $0.112(0.018)$ & $0.095(0.012)$ & $0.110(0.012)$ & $0.128(0.012)$ & $0.139(0.019)$ & 4114,5017 \\
\hline Germany & 43.19 & $0.128(0.009)$ & $0.105(0.017)$ & $0.098(0.011)$ & $0.146(0.008)$ & $0.157(0.011)$ & $0.157(0.016)$ & 3572,4698 \\
\hline Ireland & 52.07 & $0.110(0.015)$ & $0.133(0.017)$ & $0.140(0.018)$ & $0.079(0.020)$ & $0.040(0.028)$ & $0.093(0.022)$ & 2113,1945 \\
\hline Italy & 51.29 & $0.006(0.007)$ & $-0.002(0.011)$ & $0.010(0.008)$ & $0.001(0.006)$ & $-0.021(0.014)$ & $0.046(0.021)$ & 4638,4404 \\
\hline Netherlands & 48.05 & $0.200(0.010)$ & $0.144(0.017)$ & $0.187(0.011)$ & $0.191(0.008)$ & $0.196(0.009)$ & $0.232(0.013)$ & 3125,3378 \\
\hline Spain & 52.65 & $0.054(0.012)$ & $0.083(0.017)$ & $0.068(0.015)$ & $0.058(0.015)$ & $-0.005(0.015)$ & $0.065(0.014)$ & 3155,2837 \\
\hline \multicolumn{9}{|c|}{ PRIVATE SECTOR } \\
\hline Austria & 60.61 & $0.292(0.008)$ & $0.286(0.011)$ & $0.286(0.009)$ & $0.275(0.009)$ & $0.273(0.009)$ & $0.266(0.013)$ & 6469,4205 \\
\hline Belgium & 57.65 & $0.137(0.009)$ & $0.121(0.011)$ & $0.135(0.010)$ & $0.120(0.013)$ & $0.140(0.012)$ & $0.199(0.015)$ & 4271,3137 \\
\hline Britain & 56.43 & $0.306(0.008)$ & $0.269(0.011)$ & $0.304(0.010)$ & $0.309(0.010)$ & $0.326(0.012)$ & $0.311(0.014)$ & 8980,6934 \\
\hline Denmark & 63.63 & $0.134(0.008)$ & $0.104(0.011)$ & $0.115(0.006)$ & $0.091(0.008)$ & $0.167(0.010)$ & $0.240(0.014)$ & 5169,2955 \\
\hline Finland & 59.95 & $0.167(0.008)$ & $0.121(0.013)$ & $0.135(0.010)$ & $0.146(0.012)$ & $0.199(0.014)$ & $0.242(0.019)$ & 5413,3616 \\
\hline France & 58.79 & $0.202(0.007)$ & $0.180(0.010)$ & $0.156(0.008)$ & $0.170(0.008)$ & $0.201(0.011)$ & $0.228(0.013)$ & 10309,7227 \\
\hline Germany & 62.41 & $0.262(0.006)$ & $0.294(0.012)$ & $0.253(0.008)$ & $0.231(0.005)$ & $0.247(0.006)$ & $0.282(0.009)$ & 13335,8031 \\
\hline Ireland & 56.56 & $0.273(0.010)$ & $0.264(0.020)$ & $0.267(0.012)$ & $0.263(0.012)$ & $0.267(0.015)$ & $0.313(0.020)$ & 4684,3597 \\
\hline Italy & 63.83 & $0.153(0.006)$ & $0.145(0.011)$ & $0.111(0.006)$ & $0.130(0.005)$ & $0.146(0.008)$ & $0.194(0.010)$ & 10255,5812 \\
\hline Netherlands & 64.31 & $0.208(0.007)$ & $0.177(0.011)$ & $0.176(0.007)$ & $0.176(0.007)$ & $0.217(0.008)$ & $0.278(0.010)$ & 10491,5821 \\
\hline Spain & 65.39 & $0.230(0.008)$ & $0.252(0.011)$ & $0.206(0.008)$ & $0.205(0.008)$ & $0.244(0.012)$ & $0.207(0.020)$ & 11790,6241 \\
\hline
\end{tabular}

Notes: (i) Raw wage gap is measured as the difference of the log male and log female hourly wage. The log wage was calculated from the ECHP variables as log (wage) $=$ log (PI211MG * $(12 / 52) /$ PE005A) $=\log$ (normal gross monthly earnings from main job including overtime * (12/52)/ hours in main job including overtime). It was then deflated to 2001 prices using harmonised indices of consumer prices (HICP) from the Eurostat Yearbook 2003. (ii) Except for the coefficients in italics, all coefficients are significantly different from zero at $5 \%$ level of significance. 
Table 2 - Estimated Wage gap (and percentage raw gap explained by the model)

\begin{tabular}{|c|c|c|c|c|c|c|}
\hline \\
\hline & OLS & $10 \%$ & $25 \%$ & $50 \%$ & $75 \%$ & $90 \%$ \\
\hline \multicolumn{7}{|c|}{ PUBLIC SECTOR } \\
\hline \multirow[t]{2}{*}{ Austria } & $0.163^{* * *}$ & $0.168^{* * *}$ & $0.117^{* * *}$ & $0.117^{* * *}$ & $0.130^{* * *}$ & $0.133^{* * *}$ \\
\hline & -20.7 & -9.8 & 4.1 & -34.5 & -39.8 & -15.7 \\
\hline \multirow[t]{2}{*}{ Belgium } & $0.103^{* * *}$ & $0.127^{* * *}$ & $0.070^{* * *}$ & $0.094^{* * *}$ & $0.094^{* * *}$ & $0.135^{* * *}$ \\
\hline & -41.1 & -108.2 & -20.7 & -184.8 & -44.6 & 0.7 \\
\hline \multirow[t]{2}{*}{ Britain } & $0.186^{* * *}$ & $0.124^{* * *}$ & $0.161^{* * *}$ & $0.151^{* * * *}$ & $0.213^{* * *}$ & $0.229^{* * *}$ \\
\hline & 12.3 & 41.8 & 13.0 & 30.1 & -8.1 & -5.5 \\
\hline \multirow[t]{2}{*}{ Denmark } & $0.086^{* * *}$ & $0.092^{* * *}$ & $0.058^{* * *}$ & $0.079^{* * *}$ & $0.116^{* * *}$ & $0.164^{* * *}$ \\
\hline & 24.6 & 28.1 & 31.8 & 24.8 & 2.5 & 6.3 \\
\hline \multirow[t]{2}{*}{ Finland } & $0.202^{* * *}$ & $0.134^{* * *}$ & $0.145^{* * *}$ & $0.207^{* * *}$ & $0.244^{* * *}$ & $0.313^{* * *}$ \\
\hline & 22.0 & 18.3 & 26.0 & 20.4 & 22.8 & -2.0 \\
\hline \multirow[t]{2}{*}{ France } & $0.140^{* * *}$ & $0.163^{* * *}$ & $0.140^{* * *}$ & $0.110^{* * *}$ & $0.115^{* * *}$ & $0.187^{* * *}$ \\
\hline & -20.7 & -45.5 & -47.4 & 0.0 & 10.2 & -34.5 \\
\hline \multirow[t]{2}{*}{ Germany } & $0.151^{* * *}$ & $0.178^{* * *}$ & $0.149^{* * *}$ & $0.157^{* * *}$ & $0.132^{* * *}$ & $0.131^{* * * *}$ \\
\hline & -18.0 & -69.5 & -52.0 & -7.5 & 15.9 & 17.6 \\
\hline \multirow[t]{2}{*}{ Ireland } & $0.199^{* * *}$ & $0.394^{* * *}$ & $0.202^{* * *}$ & $0.188^{* * *}$ & $0.147^{* * *}$ & $0.214^{* * * *}$ \\
\hline & -80.9 & -196.2 & -44.3 & -138.0 & -267.5 & -130.1 \\
\hline Italy & $\begin{array}{c}0.118^{* * * *} \\
-1866.7\end{array}$ & $\begin{array}{c}0.086^{* * *} \\
4400.0\end{array}$ & $\begin{array}{l}0.089^{\text {*** }} \\
-790.0\end{array}$ & $\begin{array}{c}0.107^{\text {*** }} \\
-10600.0\end{array}$ & $\begin{array}{c}0.149^{\text {*** }} \\
809.5\end{array}$ & $\begin{array}{l}0.222^{\text {**** }} \\
-382.6\end{array}$ \\
\hline \multirow[t]{2}{*}{ Netherlands } & $0.128^{* * *}$ & $0.100^{* * *}$ & $0.103^{\text {**** }}$ & $0.124^{* * * *}$ & $0.165^{* * *}$ & $0.204^{\text {***** }}$ \\
\hline & 36.0 & 30.6 & 44.9 & 35.1 & 15.8 & 12.1 \\
\hline \multirow[t]{2}{*}{ Spain } & $0.096^{* * *}$ & $0.083^{* * *}$ & $0.093^{* * *}$ & $0.113^{* * * *}$ & $0.096^{* * *}$ & $0.118^{* * * *}$ \\
\hline & -77.8 & 0.0 & -36.8 & -94.8 & 2020.0 & -81.5 \\
\hline \multicolumn{7}{|c|}{ PRIVATE SECTOR } \\
\hline \multirow[t]{2}{*}{ Austria } & $0.285^{* * *}$ & $0.290^{* * *}$ & $0.257^{* * * *}$ & $0.259^{* * * *}$ & $0.268^{* * * 3}$ & $0.283^{* * * *}$ \\
\hline & 2.4 & -1.4 & 10.1 & 5.8 & 1.8 & -6.4 \\
\hline \multirow[t]{2}{*}{ Belgium } & $0.165^{* * * *}$ & $0.136^{* * *}$ & $0.189^{* * *}$ & $0.201^{* * *}$ & $0.158^{* * *}$ & $0.162^{* * *}$ \\
\hline & -20.4 & -12.4 & -40.0 & -67.5 & -12.9 & 18.6 \\
\hline \multirow[t]{2}{*}{ Britain } & $0.212^{* * * *}$ & $0.173^{* * *}$ & $0.197^{* * *}$ & $0.223^{* * *}$ & $0.188^{* * *}$ & $0.211^{* * *}$ \\
\hline & 30.7 & 35.7 & 35.2 & 27.8 & 42.3 & 32.2 \\
\hline \multirow[t]{2}{*}{ Denmark } & $0.122^{* * * *}$ & $0.081^{* * *}$ & $0.111^{* * *}$ & $0.097^{* * *}$ & $0.128^{* * *}$ & $0.197^{* * *}$ \\
\hline & 9.0 & 22.1 & 3.5 & -6.6 & 23.4 & 17.9 \\
\hline \multirow[t]{2}{*}{ Finland } & $0.218^{* * * *}$ & $0.158^{* * *}$ & $0.175^{* * *}$ & $0.235^{* * *}$ & $0.218^{* * *}$ & $0.299^{* * *}$ \\
\hline & -30.5 & -30.6 & -29.6 & -61.0 & -9.5 & -23.6 \\
\hline \multirow[t]{2}{*}{ France } & $0.159^{* * * * 2}$ & $0.169^{* * *}$ & $0.128^{* * *}$ & $0.145^{* * *}$ & $0.165^{* * *}$ & $0.245^{* * *}$ \\
\hline & 21.3 & 6.1 & 17.9 & 14.7 & 17.9 & -7.5 \\
\hline \multirow[t]{2}{*}{ Germany } & $0.196^{* * * *}$ & $0.229^{* * *}$ & $0.190^{* * *}$ & $0.200^{* * *}$ & $0.199^{* * *}$ & $0.216^{* * *}$ \\
\hline & 25.1 & 22.1 & 24.9 & 13.4 & 19.4 & 23.4 \\
\hline \multirow[t]{2}{*}{ Ireland } & $0.224^{* * * * *}$ & $0.131^{* * *}$ & $0.179^{* * *}$ & $0.246^{* * *}$ & $0.256^{* * *}$ & $0.237^{* * *}$ \\
\hline & 17.9 & 50.4 & 33.0 & 6.5 & 4.1 & 24.3 \\
\hline Italy & $0.188^{* * * *}$ & $0.194^{* * *}$ & $0.168^{* * *}$ & $0.167^{* * *}$ & $0.205^{* * *}$ & $0.235^{* * *}$ \\
\hline & -22.9 & -33.8 & -51.4 & -28.5 & -40.4 & -21.1 \\
\hline Netherlands & $0.151^{* * * *}$ & $0.135^{* * * * *}$ & $0.134^{3 * 3 *}$ & $0.143^{* \cdots * 3}$ & $0.169^{* *_{*}^{*}}$ & $0.210^{* * * * *}$ \\
\hline & 27.4 & 23.7 & 23.9 & 18.8 & 22.1 & 24.5 \\
\hline Spain & $0.230^{* * * *}$ & $0.167^{* * *}$ & $0.202^{* * *}$ & $0.235^{* * *}$ & $0.248^{* * *}$ & $0.256^{* * *}$ \\
\hline & 0.0 & 33.7 & 1.9 & -14.6 & -1.6 & -23.7 \\
\hline
\end{tabular}

Notes: (i) The model includes dummies for whether training was received in the last year, age, education, tenure, marital status, health status, any experience of unemployment since 1989, part-time status, fixed term and casual contracts, private sector firm size, occupation, region (where possible), industry and year. Dummies were also included for cases where there were a very large number of missing values. See the Appendix for further details. (ii) Level of significance: * $10 \%$, ** 5\%, *** $1 \%$. 
Figure 1

Raw wage distributions by country and public/private sector
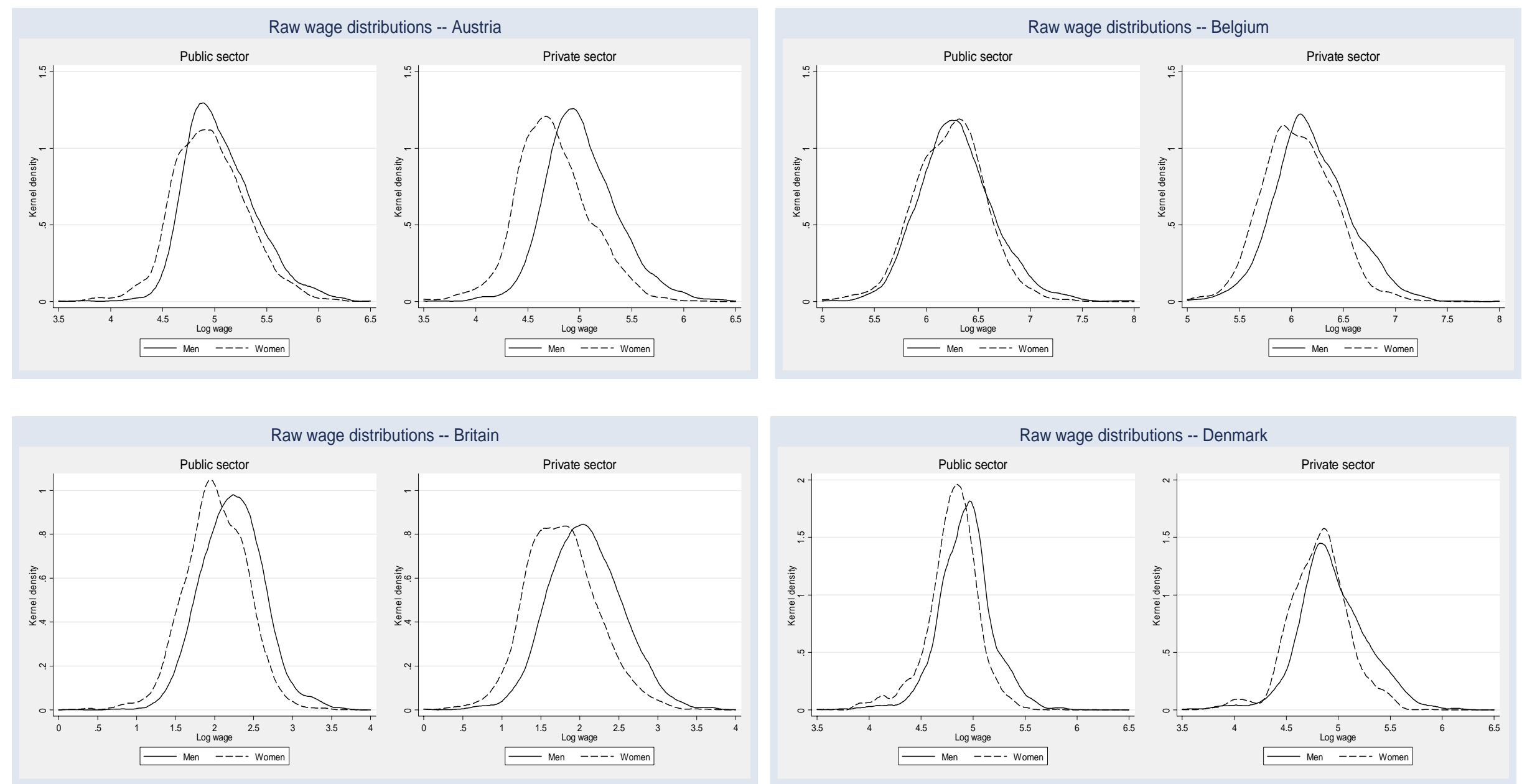
Figure 1 (continued)

Raw wage distributions by country and public/private sector
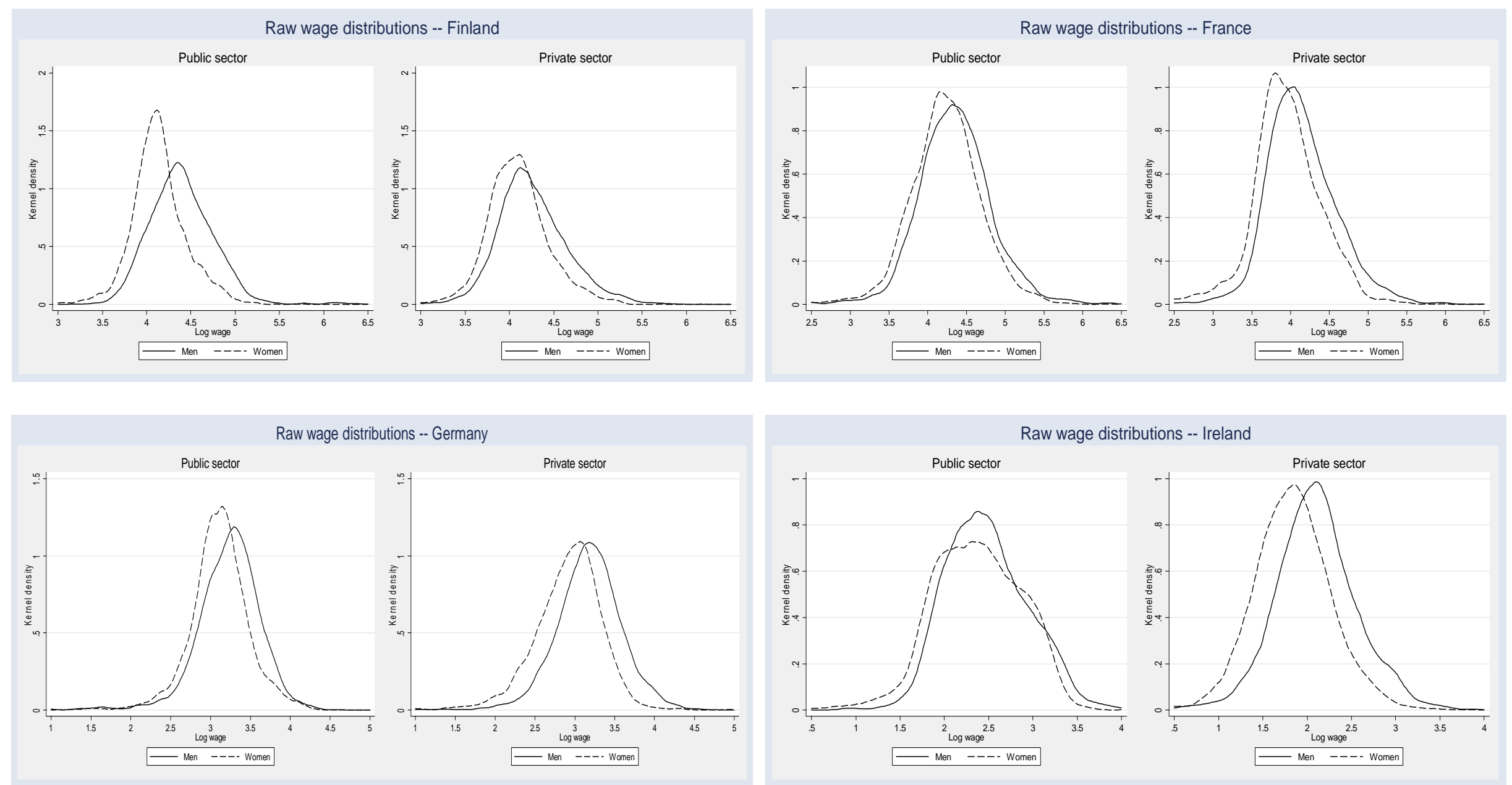
Figure 1 (continued)

Raw wage distributions by country and public/private sector
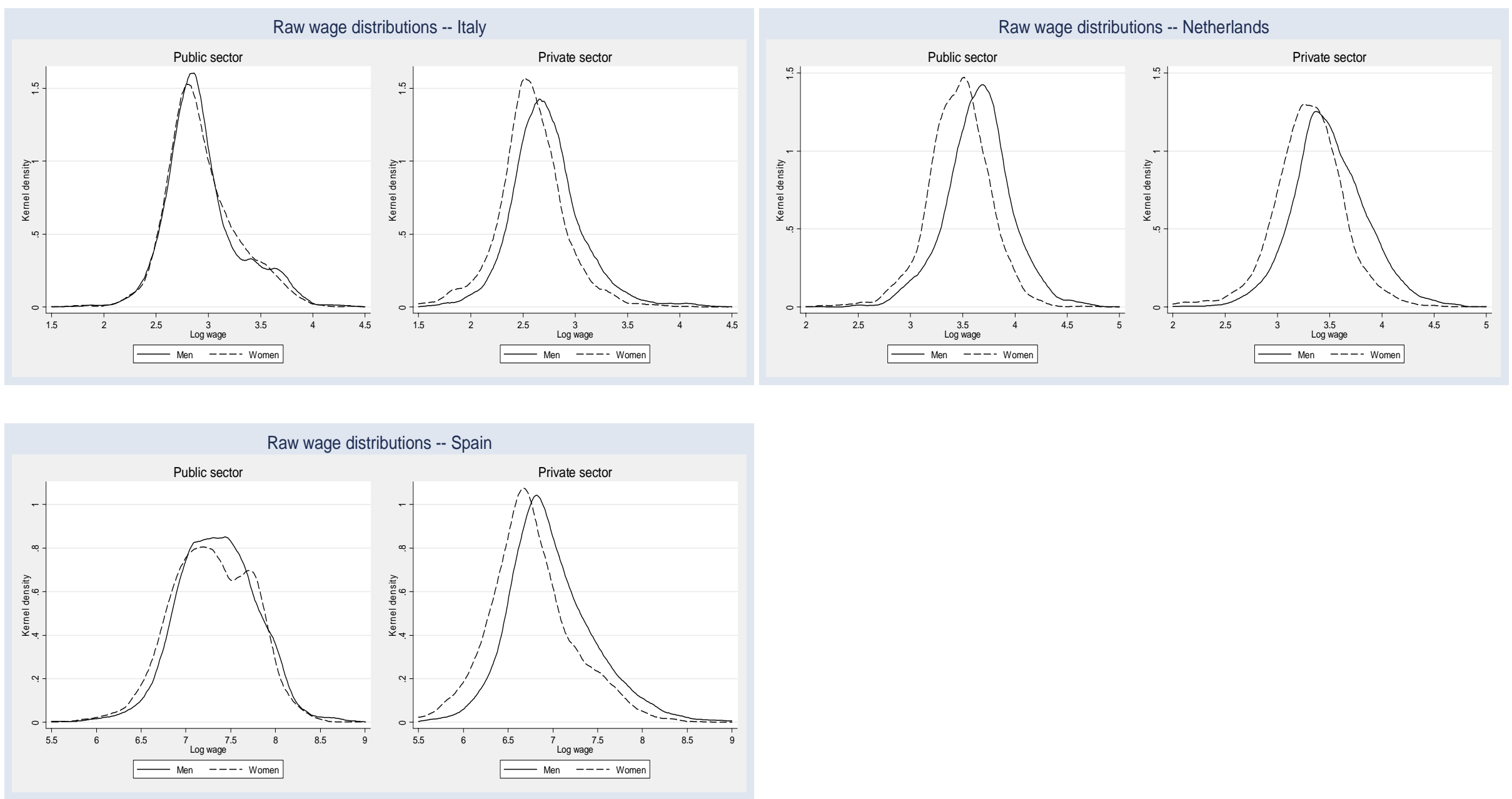

22 
Figure 2

Gender wage gap due to differences in returns evaluated at men's characteristics.

Industry and occupation dummies included
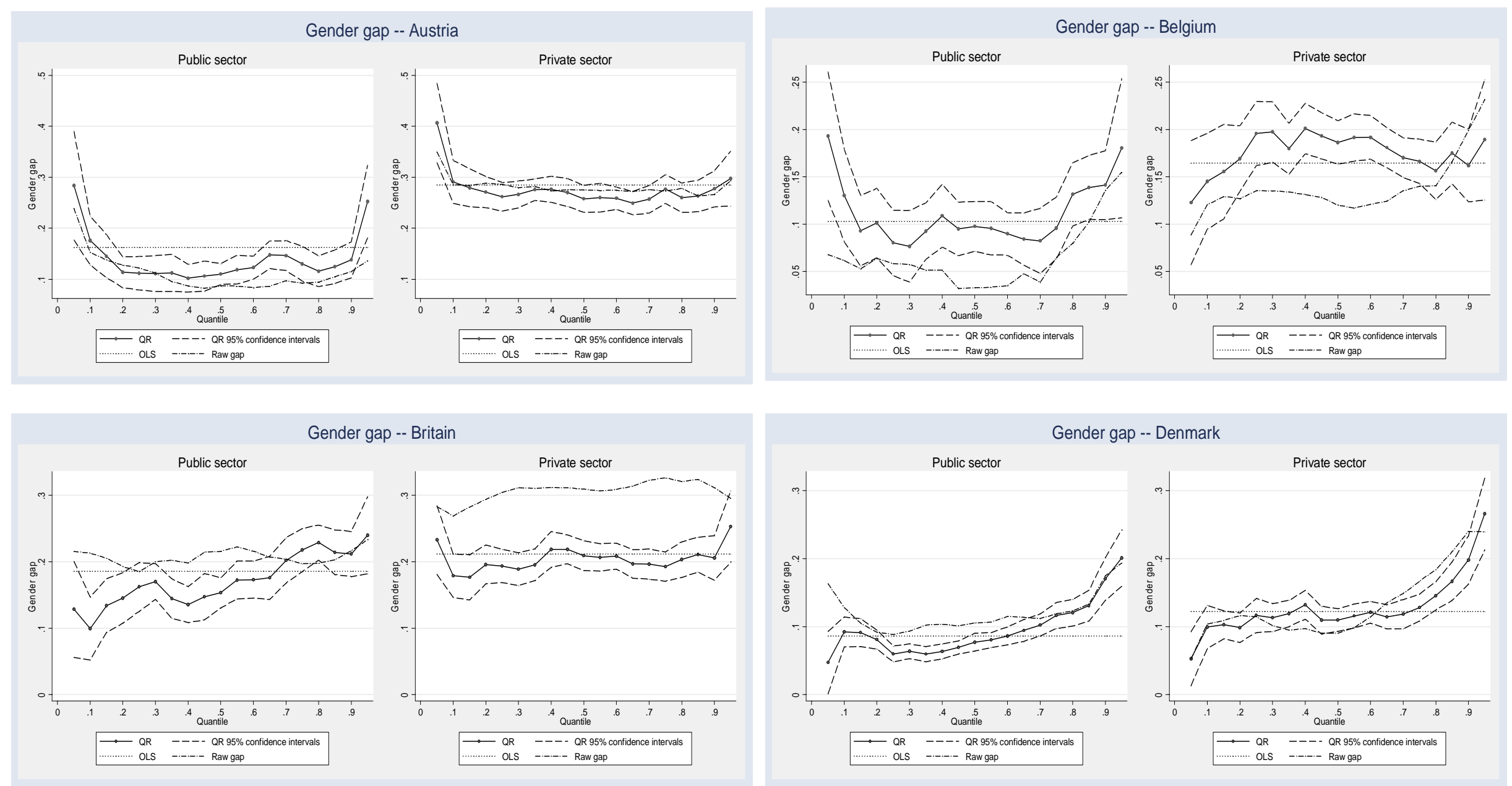
Figure 2 (continued)

Gender wage gap due to differences in returns evaluated at men's characteristics. Industry and occupation dummies included
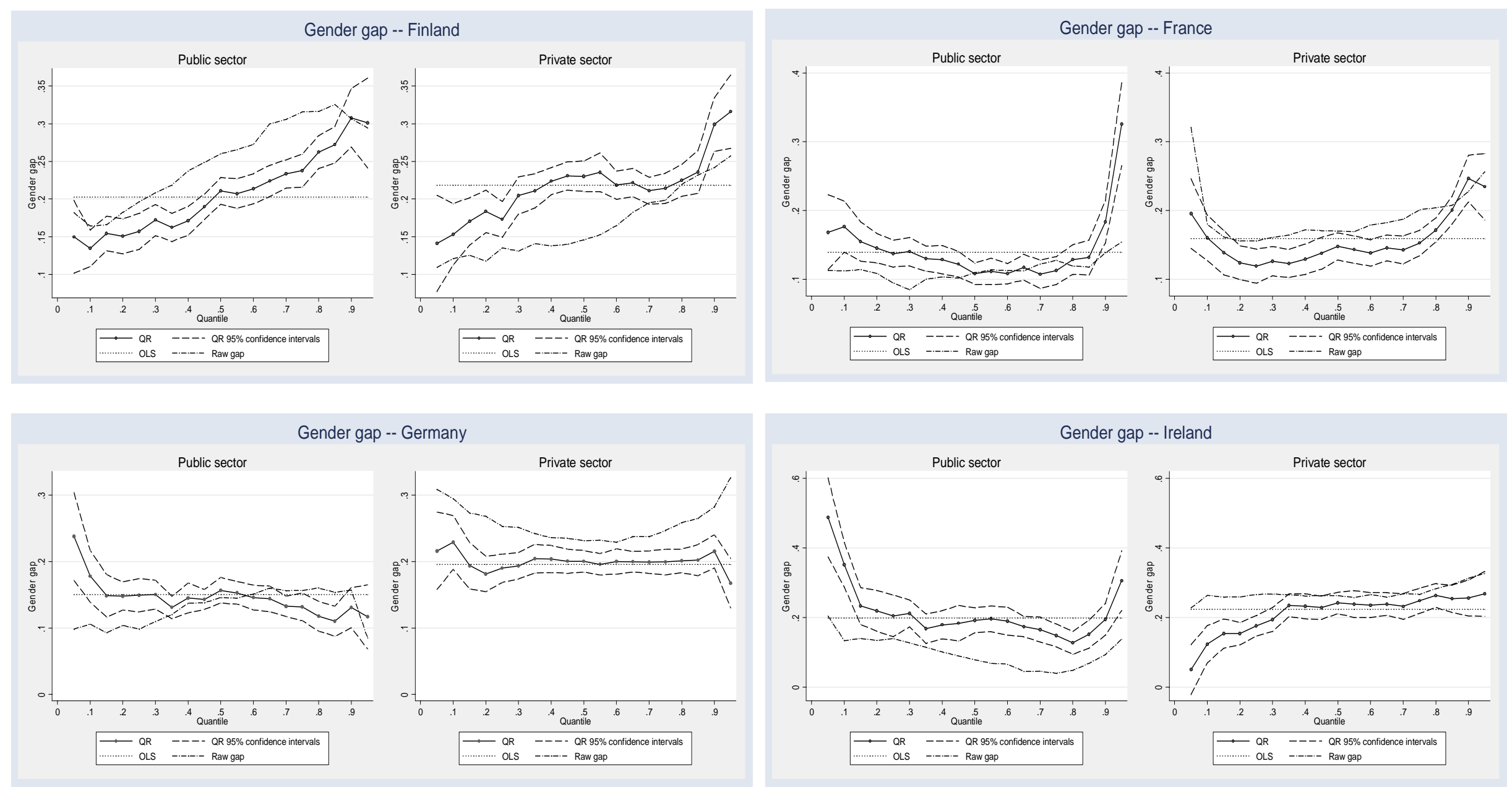
Figure 2 (continued)

Gender wage gap due to differences in returns evaluated at men's characteristics. Industry and occupation dummies included
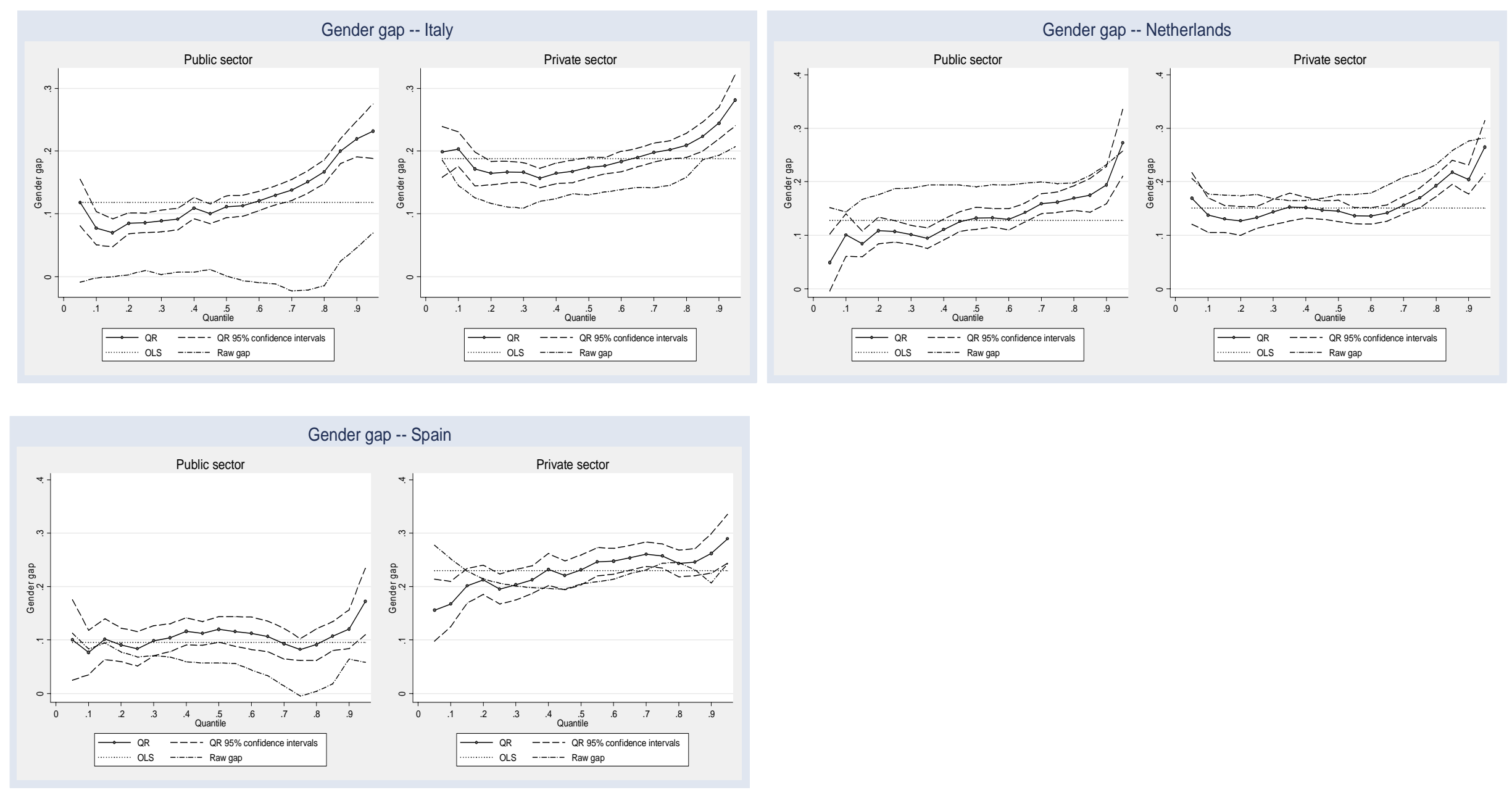


\section{Figure 3}

Gender wage gap due to differences in returns evaluated at men's characteristics. Industry and occupation dummies omitted
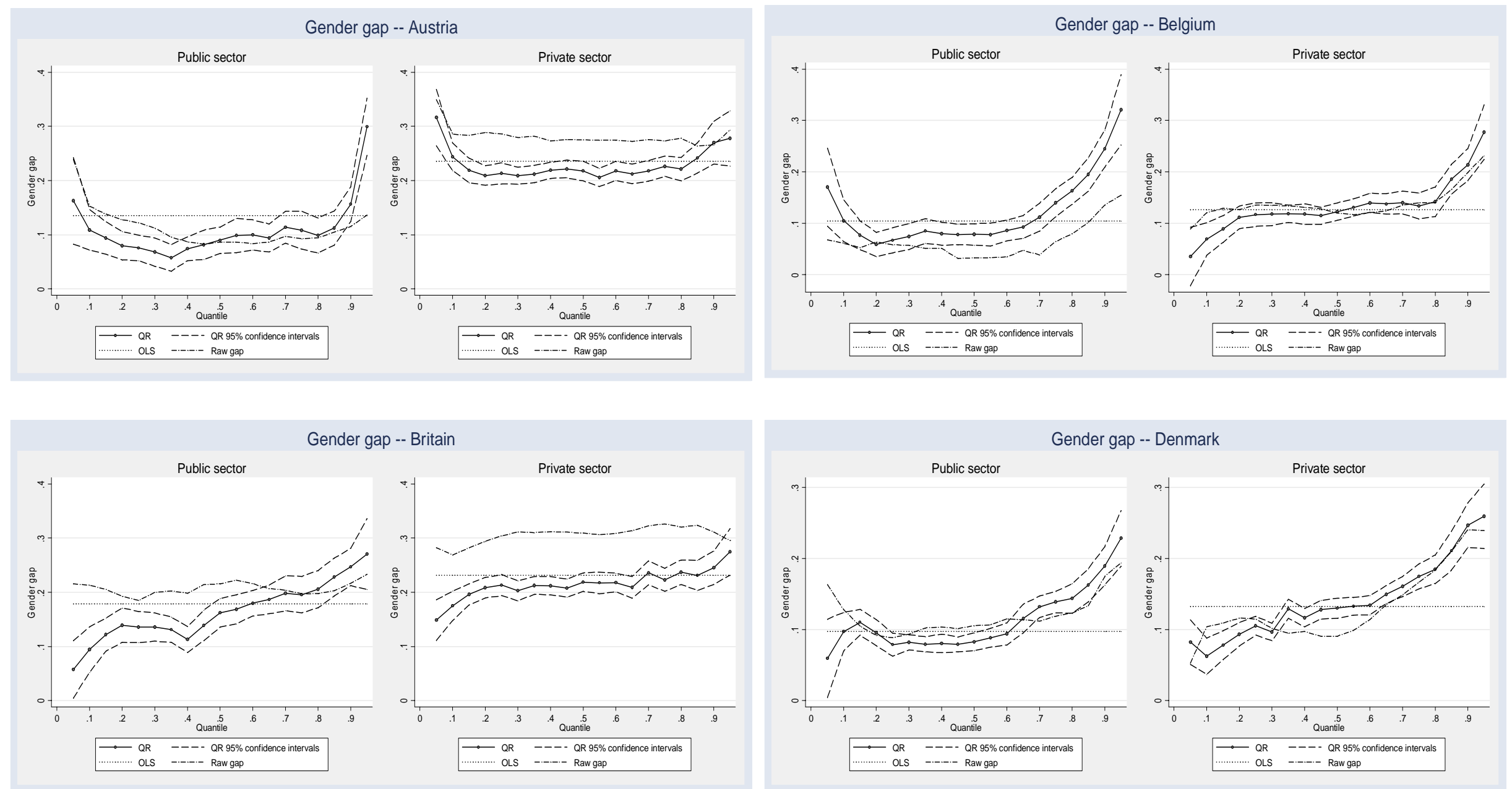
Figure 3 (continued)

Gender wage gap due to differences in returns evaluated at men's characteristics. Industry and occupation dummies omitted
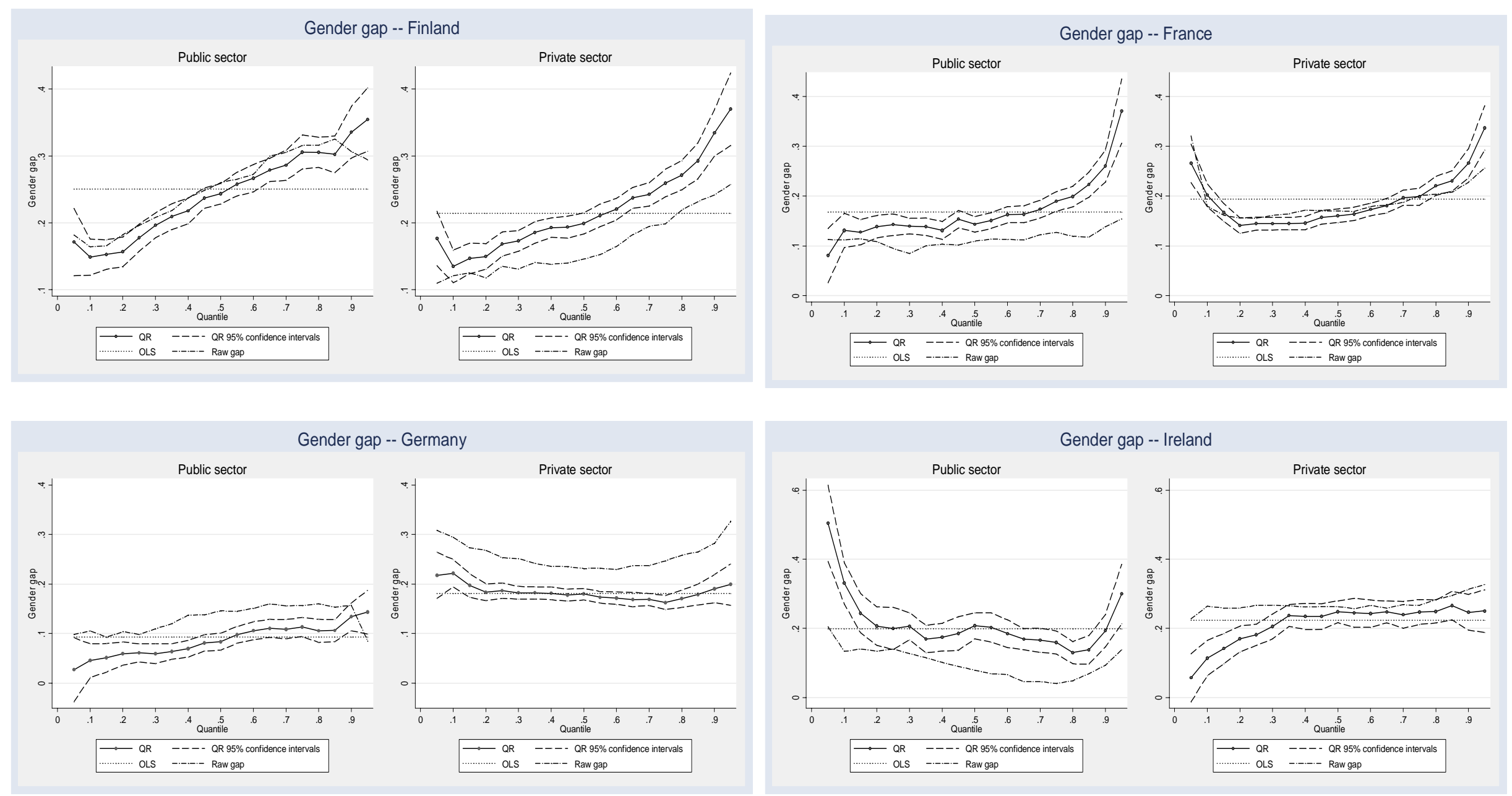
Figure 3 (continued)

Gender wage gap due to differences in returns evaluated at men's characteristics. Industry and occupation dummies omitted
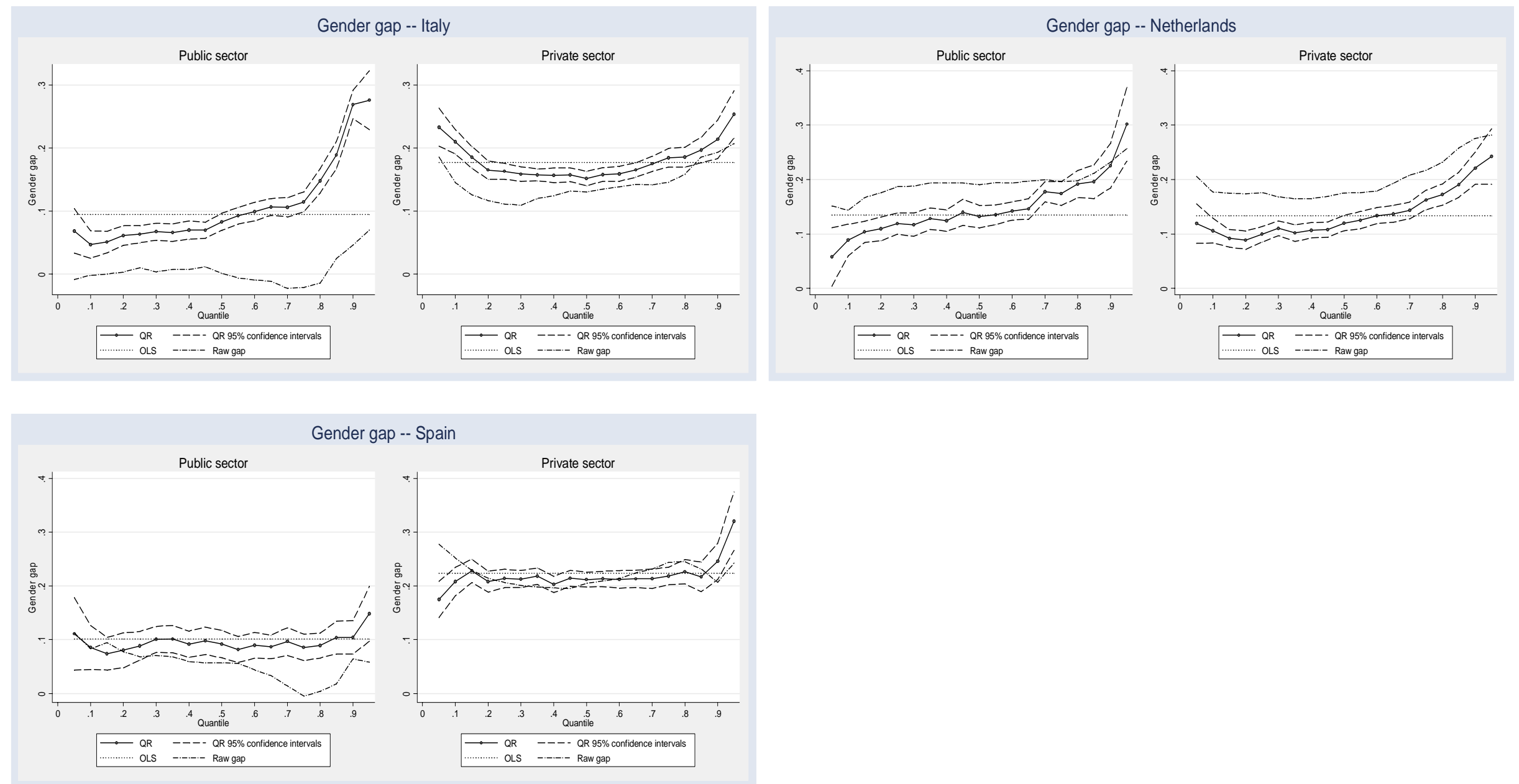


\section{DATA APPENDIX:}

\section{Selection of Estimating Samples and Sample Sizes}

The selection criteria are outlined in the text, and result in sample sizes as given in the last column of Appendix Table 1. The various industry and occupation dummies were combined in the following cases: (i) where there were small cell sizes (less than $1 \%$ of observations for both sexes); or (ii) where there was strong gender segregation (less than $1 \%$ of one sex in a cell).

For the industry dummies, the base case in the public sector is administration, and the base case in the private sector is manufacturing. The table below shows how dummies were combined for each sector and country. For the public sector (where industry structure varies substantially across countries), the table lists the dummies combined and those included separately. Note that, when energy is combined with manufacturing, it is simply left in the base case. For the private sector, the table lists only combined dummies. The others are all included separately. The full industry list is: Agriculture (all observations dropped), energy, manufacturing, construction, retail, hotels, communications, finance, property, administration, education, social services, other, and missing industry.

For the occupational dummies, the base case is unskilled. The most common form of occupational segregation is in the public sector, where there are very few female craft workers or operatives. These categories were combined with service and shop workers (this seemed better than combining them with unskilled). Full occupational list is: Manager, professional, associate professional, clerical worker, service worker, agricultural worker (all observations dropped), craft worker, operative, unskilled/other, missing occupation.

Germany: to account for differences in wage determination between east and west in post-unification Germany, following a pooling test we interacted the following variables with a dummy variable for Eastern Germany: age, education, health status, any experience of unemployment since 1989, fixed term contract, occupation, firm size (private sector) and year. 


\begin{tabular}{|c|c|c|c|c|}
\hline Country & Sector & Industry dummies & $\begin{array}{l}\text { Occupation } \\
\text { dummies }\end{array}$ & $\begin{array}{l}\text { Final no. of pooled } \\
\text { observations [males, } \\
\text { females] }\end{array}$ \\
\hline \multirow[t]{2}{*}{ Austria } & Public & $\begin{array}{l}\text { Combined: energy, manuf, } \\
\text { constr, retail, hotel and finance } \\
\text { Separate: comms, property, } \\
\text { education, social, other. }\end{array}$ & $\begin{array}{l}\text { Combined: } \\
\text { service worker, } \\
\text { craft, operative }\end{array}$ & 2389,2214 \\
\hline & Private & $\begin{array}{l}\text { Combined: (1) energy \& } \\
\text { manuf; (2) admin, educ \& } \\
\text { social. }\end{array}$ & & 6469,4205 \\
\hline \multirow[t]{2}{*}{ Belgium } & Public & $\begin{array}{l}\text { Combined: energy, manuf, } \\
\text { constr, retail \& hotel. } \\
\text { Separate: comms, finance, } \\
\text { property, education, social, } \\
\text { other. }\end{array}$ & $\begin{array}{l}\text { Combined: } \\
\text { service worker, } \\
\text { craft, operative }\end{array}$ & 2257,2466 \\
\hline & Private & $\begin{array}{l}\text { Combined: (1) energy \& } \\
\text { manuf; (2) admin \& educ. }\end{array}$ & & 4271,3137 \\
\hline \multirow[t]{2}{*}{ Britain } & Public & $\begin{array}{l}\text { Combined: energy, manuf, } \\
\text { constr, retail, hotel and finance } \\
\text { Separate: comms, property, } \\
\text { education, social, other. }\end{array}$ & $\begin{array}{l}\text { Combined: } \\
\text { service worker, } \\
\text { craft, operative }\end{array}$ & 2099,3918 \\
\hline & Private & Combined: admin and educ. & & 8980,6934 \\
\hline \multirow[t]{2}{*}{ "Denmark } & Public & $\begin{array}{l}\text { Combined: energy, manuf, } \\
\text { constr, retail, hotel and finance } \\
\text { Separate: comms, property, } \\
\text { education, social, other. }\end{array}$ & $\begin{array}{l}\text { Combined: } \\
\text { service worker, } \\
\text { craft, operative }\end{array}$ & 1984,3922 \\
\hline & Private & $\begin{array}{l}\text { Combined: (1) energy \& } \\
\text { manuf; (2) admin, educ \& } \\
\text { social. }\end{array}$ & & 5169,2955 \\
\hline \multirow[t]{2}{*}{ Finland } & Public & $\begin{array}{l}\text { Combined: energy, constr, } \\
\text { retail, hotel and finance } \\
\text { Separate: manuf, comms, } \\
\text { property, education, social, } \\
\text { other. }\end{array}$ & $\begin{array}{l}\text { Combined: } \\
\text { service worker, } \\
\text { craft, operative }\end{array}$ & 2240,4153 \\
\hline & Private & $\begin{array}{l}\text { Combined: (1) energy \& } \\
\text { manuf; (2) admin, educ \& } \\
\text { social. }\end{array}$ & & 5413,3616 \\
\hline \multirow[t]{2}{*}{ France } & Public & $\begin{array}{l}\text { Combined: constr, retail \& } \\
\text { hotel. } \\
\text { Separate: energy, manuf, } \\
\text { comms, finance, property, } \\
\text { education, social, other. }\end{array}$ & $\begin{array}{l}\text { Combined: } \\
\text { service worker, } \\
\text { craft, operative }\end{array}$ & 4114,5017 \\
\hline & Private & $\begin{array}{l}\text { Combined: (1) energy \& } \\
\text { manuf; (2) admin \& educ. }\end{array}$ & & 10309,7227 \\
\hline
\end{tabular}




\begin{tabular}{|c|c|c|c|c|}
\hline Country & Sector & Industry dummies & $\begin{array}{l}\text { Occupation } \\
\text { dummies }\end{array}$ & $\begin{array}{l}\text { Final no. of obs } \\
\text { [males, females] }\end{array}$ \\
\hline \multirow[t]{2}{*}{ Germany } & Public & $\begin{array}{l}\text { Combined: energy, manuf, } \\
\text { constr, retail, hotel \& property } \\
\text { Separate: comms, finance, } \\
\text { education, social, other. }\end{array}$ & $\begin{array}{l}\text { Combined: } \\
\text { service worker, } \\
\text { craft, operative }\end{array}$ & 3572,4698 \\
\hline & Private & $\begin{array}{l}\text { Combined: (1) energy \& } \\
\text { manuf; (2) admin, educ \& } \\
\text { social. }\end{array}$ & & 13335,8031 \\
\hline \multirow[t]{2}{*}{ Ireland } & Public & $\begin{array}{l}\text { Combined: energy, manuf, } \\
\text { constr, retail \& hotel } \\
\text { Separate: comms, finance, } \\
\text { property, education, social, } \\
\text { other. }\end{array}$ & $\begin{array}{l}\text { Combined: } \\
\text { service worker, } \\
\text { craft, operative }\end{array}$ & 2113,1945 \\
\hline & Private & $\begin{array}{l}\text { Combined: (1) energy \& } \\
\text { manuf; (2) admin, educ \& } \\
\text { social. }\end{array}$ & & 4684,3597 \\
\hline \multirow[t]{2}{*}{ Italy } & Public & $\begin{array}{l}\text { Combined: constr, retail, } \\
\text { hotel, finance, property. } \\
\text { Separate: energy, manuf, } \\
\text { comms, education, social, } \\
\text { other. }\end{array}$ & $\begin{array}{l}\text { Combined: (1) } \\
\text { manager \& } \\
\text { professional; (2) } \\
\text { service worker, } \\
\text { craft \& operative }\end{array}$ & 4638,4404 \\
\hline & Private & $\begin{array}{l}\text { Combined: admin, educ \& } \\
\text { social. }\end{array}$ & $\begin{array}{c}\text { Combined: } \\
\text { manager \& } \\
\text { professional. }\end{array}$ & 10255,5812 \\
\hline \multirow[t]{2}{*}{$\begin{array}{l}\text { Netherla } \\
\text { nds }\end{array}$} & Public & $\begin{array}{l}\text { Combined: energy, manuf, } \\
\text { constr, retail, hotel, comms \& } \\
\text { finance. } \\
\text { Separate: property, education, } \\
\text { social, other. }\end{array}$ & $\begin{array}{l}\text { Combined: } \\
\text { service worker, } \\
\text { craft, operative }\end{array}$ & 3125,3378 \\
\hline & Private & Combined: admin \& educ. & & 10491,5821 \\
\hline \multirow[t]{2}{*}{ Spain } & Public & $\begin{array}{l}\text { Combined: energy, manuf, } \\
\text { constr, retail, hotel \& finance. } \\
\text { Separate: comms, property, } \\
\text { education, social, other. }\end{array}$ & $\begin{array}{l}\text { Combined: (1) } \\
\text { manager \& } \\
\text { professional; (2) } \\
\text { service worker, } \\
\text { craft \& operative }\end{array}$ & 3155,2837 \\
\hline & Private & $\begin{array}{l}\text { Combined: admin, educ \& } \\
\text { social. }\end{array}$ & & 11790,6241 \\
\hline
\end{tabular}

